\title{
Pneumologia
}

\section{Pneumonia by Kocuria rosea: case report and literature review}

Tatiana Paola Pacheco Páez ${ }^{1}$, German Gutierrez Parra², Alirio Rodrigo Bastidas Goyes ${ }^{3, \dagger}$, María Daniela Hernández Arcila ${ }^{4}$, Paula Marcela Alcaraz Cañizares ${ }^{4}$, Julio César García Casallas ${ }^{5}$, Daniel Martin Arsanios ${ }^{6}$

${ }^{1}$ Medical Resident of Clinical Pharmacology, Sabana University, Colombia

${ }^{2}$ Medical Resident of Critical Care and Intensive Care Medicine, Sabana University, Colombia

${ }^{3}$ Internist, Pneumologist, Epidemiologist, Sabana University Clinic, Colombia

${ }^{4}$ Eighth Semester Student, Sabana University, Colombia

5Internist, Clinical Pharmacologist, Sabana University Clinic, Colombia

Abstract

${ }^{6}$ Medical Resident of Internal Medicine, Sabana University, Colombia

\section{English:}

Species from the genus Kocuria are strictly aerobic, catalase-positive, coagulase-negative and Gram-positive bacteria. This article deals with the case of a 71-year-old patient with severe community-acquired pneumonia (CAP) caused by Kocuria rosea. An exhaustive search of the available medical literature revealed no previous reports regarding pneumonia caused by K. rosea.

Keywords

Kocuria $\bullet$ Kocuria rosea $\cdot$ community-acquired pneumonia $\bullet$ immunosuppression

\section{Pneumonia cu Kocuria rosea: prezentare de caz și revizie a literaturii}

Rezumat

Romanian:

Speciile genului Kocuria sunt bacterii Gram pozitive strict aerobe, catazo-pozitive, coagulazo-negative. Acest articol prezintă cazul unui pacient de 71 de ani cu o pneumonie comunitară severă cauzată de Kocuria rosea. 0 cercetare extensivă a literaturii medicale disponibile nu a identificat nici o altă raportare anterioară a unui caz de pneumonie cu K. rosea.

Cuvinte-cheie

Kocuria $・$ Kocuria rosea $\cdot$ pneumonie comunitară $\bullet$ imunodepresie

\section{Introduction}

Species from the genus Kocuria are found in the environment and form part of the normal flora in humans and other mammals. They are rare infectious pathogens present in immunocompromised individuals. They are strictly aerobic, catalase-positive, coagulase-negative, Gram-positive bacteria. Cases associated with Kocuria bacteraemia species have been reported as being related to central catheter use, peritonitis, brain abscesses, meningitis, endocarditis and acute

+Corresponding author: Alirio Rodrigo Bastidas Goyes

E-mail: Alirio.bastidas@unisabana.edu.co 
Table 1. Laboratory Tests

\begin{tabular}{|c|c|c|c|c|c|}
\hline Date & $23 / 03 / 17$ & $24 / 03 / 17$ & $25 / 03 / 17$ & $26 / 03 / 17$ & $29 / 03 / 17$ \\
\hline Leucocytes & 13720 & 18400 & 17410 & 14870 & 12850 \\
\hline Neutrophils & $86.2 \%$ & $86.9 \%$ & $83.5 \%$ & $84 \%$ & $85 \%$ \\
\hline Lymphocytes & $3.9 \%$ & $0.85 \%$ & $6.3 \%$ & $6.1 \%$ & $8.5 \%$ \\
\hline Haemoglobin & 11.3 & 10.5 & 10.9 & 11.1 & 10.9 \\
\hline Haematocrit & 33.4 & 32 & 33.6 & 33 & 27.7 \\
\hline Platelets & 174000 & 247000 & 218000 & 234000 & 216000 \\
\hline Creatinine & 1.51 & 1.67 & 2.19 & 2.19 & 1.28 \\
\hline Blood urea nitrogen & 55.2 & 60.68 & 74.44 & 74.44 & 44.5 \\
\hline
\end{tabular}

cholecystitis; however, lung infection is rare. Pertinent clinical studies are urgently needed as no management guidelines or antimicrobial susceptibility cutoff points are currently available regarding this bacterial genus, which is why as there has been a significant increase in Kocuria infection during the last 10 years. This article presents the case of a 71-year-old patient having a background of diabetes mellitus and chronic obstructive pulmonary disease who was admitted to a tertiary hospital because of severe community-acquired pneumonia (CAP) caused by Kocuria rosea; he responded favourably to antibiotic management. An exhaustive search of the available medical literature revealed no previous reports regarding pneumonia caused by K. rosea.

\section{Case Presentation}

A 71-year-old man with diabetes mellitus and dysphagia consequent to a stroke presented with 3 days of productive cough associated with dyspnoea, followed by intermittent altered consciousness. He was admitted to the emergency room with irregular breath pattern and signs of imminent respiratory failure; he required orotracheal intubation and vasoactive support. On admission (Table 1), the laboratory results showed leucocytosis with left-shift neutrophilia, increased creatinine and urea nitrogen levels, uncompensated respiratory acidosis and moderate oxygenation disorder. Chest X-ray and high-resolution computed tomography (HRCT) were requested, showing a consolidation in the upper lobe with involvement of the apical and posterior segments (Figure 1).

The patient was thus transferred to the intensive care unit (ICU) with the diagnosis of septic shock with pulmonary origin. Antibiotic management with piperacillin/tazobactam and clarithromycin was initiated. Systemic inflammatory response modulation was observed from the third day of hospitalisation in the ICU. Vasopressor support could
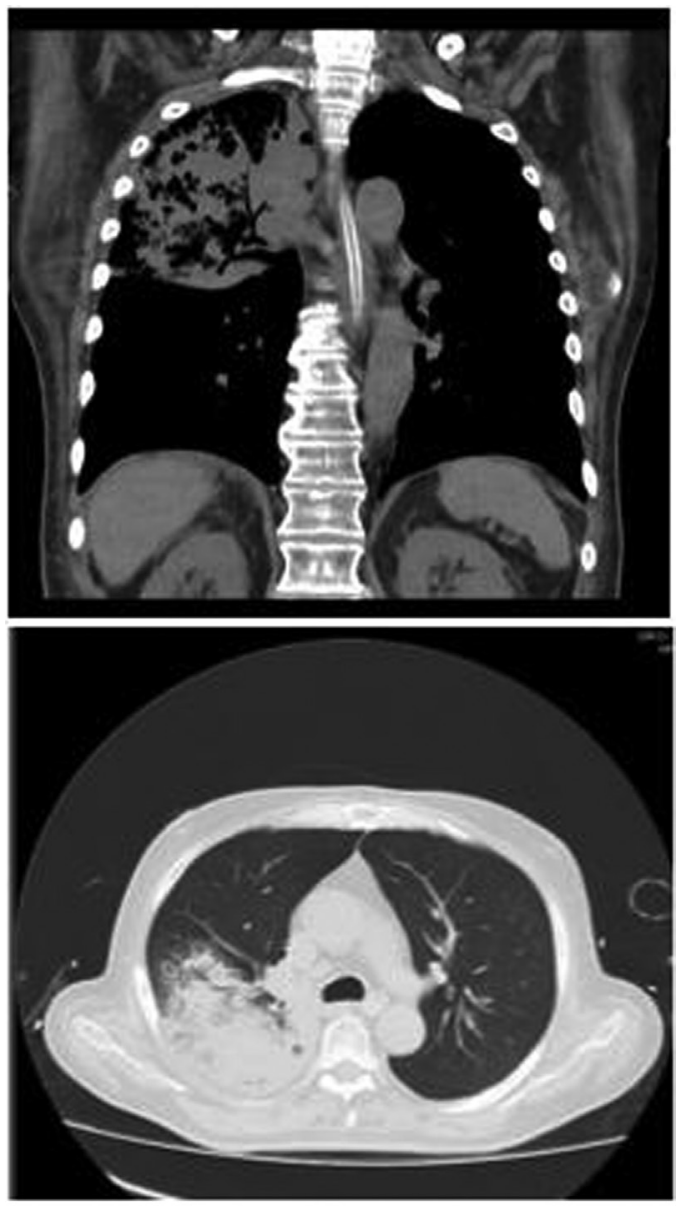

Figure 1. High-resolution computed tomography at the second day of hospital stay.

be weaned and sedation suspended, and the extubation protocol was started. Bronchoscopy with bronchoalveolar lavage (BAL) was performed with acid fast bacilli and Gram staining, reporting the presence of $K$. rosea. After 5 days, the 
modulation of the inflammatory response and hemodynamic and respiratory status were achieved.

\section{Discussion}

Kocuria are non-encapsulated, non-endospore-forming Grampositive cocci from the Micrococcaceae family, strictly aerobic, catalase positive, coagulase negative and nitrate reductase negative. The species isolated in the present case was $K$. rosea. This type of Kocuria is part of the normal microbiota of human and other mammals' skin, mouth and oropharynx, considered to be saprophytic bacteria $(1,2)$.

There are few reports regarding infection caused by the genus Kocuria in humans; this microorganism has become isolated more frequently since the end of the 20th century, and its frequency has been increasing during the last 10 years (2). Kocuria has been associated with infections (3) of the urinary tract, cholecystitis (4), catheter-associated bacteraemia (5), dacryocystitis (6), canaliculitis, keratitis (7), native valve endocarditis (8), peritonitis, descending necrotizing mediastinitis (9), brain abscess and meningitis (10). Such infections are frequently underdiagnosed due to medical consideration that this type of microorganism is mainly colonising, despite of the patient having clinical features of infection. It can be confused with other bacteria, and Kocuria can be erroneously categorised within the Staphylococcus genus. Most laboratories do not have access to advanced biochemical and molecular tests for correct isolation (2).

Risk factors for $K$. rosea infections include cancer, diabetes, chronic renal disease in continuous ambulatory peritoneal dialysis (CAPD), short bowel syndrome (SBS) and tuberculosis (2). The microorganism's entry route has most often been related to vascular access; however, a specific entry route has not been documented in patients having cerebral abscess or acute cholecystitis (presuming that it would be haematogenous) (11). As there was no vascular access in our patient, pulmonary infection might have been associated with a haematogenous route; however, Kocuria oropharyngeal colonisation associated with a history of dysphagia cannot be ruled out as this could have produced microaspirations and this microorganism's entry to the lungs.

As mentioned before, a specific description of a clinical presentation of CAP related to this bacterium could not be found in the literature; however, the clinical and radiological findings and a possible respiratory entry route posed by the isolation of $K$. rosea give a clinical definition of CAP. Right apical consolidation ruled out other infectious agents such as tuberculosis; however, diagnostic isolation for mycobacteria, fungi, Pneumocystis jirovecii and other bacteria proved negative and unusual apical infiltrate in the patient of this case as CAP could have been related to dysphagia-associated aspiration dysfunction.

Regarding the diagnosis and sampling, pneumonia management guidelines consider that samples obtained non-invasively can perform similar to samples obtained using invasive techniques, provided quantitative cultures are correctly interpreted. $K$. rosea growth in the present case was obtained by mini-BAL (giving a quantitative culture value greater than $10 \times 10^{5}$ colony-forming unit [CFU]). According to the aforementioned guidelines, a value greater than $10 \times 10^{3} \mathrm{CFU}$ is a significant count for diagnosing the isolated microorganism as being responsible for the pulmonary infection (12).

Treating infection caused by Kocuria is based on case reports; no clinical guidelines for handling it have been published to date; nevertheless, using antibiotic sensitivity cutoff points for Kocuria can be useful. Most reports today show this bacterium's sensitivity to the large group of first- and second-line antibiotics (except for ampicillin and norfloxacin) (13). However, some research groups have made use of the cutoff points used with bacteria from the Staphylococcus genus that can (obviously) lead to an unsuitable diagnosis regarding sensitivity and resistance. It has been proposed that micrococcal infections should be managed with amoxicillin/ clavulanate, doxycycline, cefuroxime or amikacin as the firstline treatment.

The patient in this case received treatment with broadspectrum antibiotics (piperacillin/tazobactam), considered appropriate for the pneumonia severity criteria according to our institutional guidelines' recommendations; a favourable evolution was achieved with these antibiotics, even though sensitivity to this antibiotic could not be demonstrated.

The resurgence as pathogens of ubiquitous bacteria that were previously considered only contaminants could be associated with the increased life expectancy of patients with chronic diseases and increased availability of invasive procedures and innovative therapies leading to immunosuppression. It is therefore important not to ignore the presence of bacteria such as the genus Kocuria in patients with risk factors to develop severe infections. More studies are needed to evaluate the virulence, pathogenic potential, risk factors and antimicrobial susceptibility patterns, always seeking a rational use of antibiotics.

\section{Conclusion}

Kocuria pneumonia is a rare infection both in immunosuppressed and immunocompetent individuals; its pathogenic mechanisms and the course of the infection 
demonstrate the importance of knowing that the timely diagnosis and the start of the antibiotic in the first hours significantly improve the prognosis of the patients as demonstrated in this case.

\section{Ethics approval and consent to participate}

Not applicable.

\section{Consent for publication}

Consent was obtained from the patient for publication of this case report and the accompanying images.

\section{Competing interests}

The authors declare that they have no competing interests.

\section{References}

1. Schumann P, Koch C. Taxonomic dissection of the genus Micrococcus: Kocuria gen. nov., Nesterenkonia gen. nov., Kytococcus gen. nov., Dermacoccus gen. nov., and Micrococcus Cohn 1872 gen. emend. International Journal of Systematic Bacteriology. 1995:45: 682-692.

2. Kandi V, Palange P, Vaish R, Bhatti AB, Kale V, Kandi MR, et al. Emerging bacterial infection: identification and clinical significance of Kocuria species. Cureus. Aug 2016. Available from: http://www. cureus.com/articles/4971-emerging-bacterial-infection-identificationand-clinical-significance-of-kocuria-species_[cited 10th April 2018].

3. Ma ES, Wong CL, Lai KT, Chan EC, Yam W, Chan AC. Kocuria kristinae infection associated with acute cholecystitis. BMC Infectious Diseases. 2005:5(1). Available from: http://bmcinfectdis. biomedcentral.com/articles/10.1186/1471-2334-5-60 [cited 10th April 2018].

4. Lai CC, Wang JY, Lin SH, Tan CK, Wang CY, Liao CH, et al. Catheter-related bacteraemia and infective endocarditis caused by Kocuria species. Clinical Microbiology and Infection. 2011:17(2): 190-192.

5. Domont F, Hamdad F, Brémond-Gignac D, Le Flèche-Matéos A. Kocuria dacryocystitis infection, caused by Kocuria ocularis sp. Nov. JMM Case Reports. 2014 Available from: http:// jmmcr.microbiologyresearch.org/content/journal/jmmcr/10.1099/ jmmcr.0.002022_[cited 10th April 2018].

6. Mattern RM, Ding J. Keratitis with Kocuria palustris and Rothia mucilaginosa in vitamin A deficiency. Case Reports in Ophthalmology. 2014:5(1): 72-77.

7. Srinivasa $\mathrm{KH}$, Agrawal N, Agarwal A, Manjunath CN. Dancing vegetations: Kocuria rosea endocarditis. Case Reports. (Jun 27 2013): bcr2013010339.

8. Lee MK, Choi SH, Ryu DW. Descending necrotizing mediastinitis caused by Kocuria rosea: a case report. BMC Infectious Diseases. 2013:13(1). Available from: http://bmcinfectdis.biomedcentral.com/articles/10.1186/1471-2334-13-475_[cited 10th April 2018].

9. Paul M, Gupta R, Khushwaha S, Thakur R. Kocuria rosea: an emerging pathogen in acute bacterial meningitis - case report. Journal of Microbiology and Antimicrobials. 2015:1(1): 4-7.

10. Altuntas F, Yildiz O, Eser B, Gündogan K, Sumerkan B, Çetin M. Catheter-related bacteremia due to Kocuria rosea in a patient undergoing peripheral blood stem cell transplantation. BMC Infectious Diseases. 2004 Available from: http://bmcinfectdis. biomedcentral.com/articles/10.1186/1471-2334-4-62_[cited 10th April 2018].

11. Kalil AC, Metersky ML, Klompas M, Muscedere J, Sweeney DA, Palmer LB, et al. Management of adults with hospital-acquired and ventilator-associated pneumonia: 2016 Clinical Practice Guidelines by the Infectious Diseases Society of America and the American Thoracic Society. Clinical Infectious Diseases. 2016:63(5): e61-e111.

12. Savini V, Catavitello C, Masciarelli G, Astolfi D, Balbinot A, Bianco A, et al. Drug sensitivity and clinical impact of members of the genus Kocuria. Journal of Medical Microbiology. 2010:59(12): 1395-1402.

13. Purty S, Saranathan R, Prashanth K, Narayanan K, Asir J, Sheela Devi $C$, et al. The expanding spectrum of human infections caused by Kocuria species: a case report and literature review. Emerging Microbes \& Infections. 2013:2(10): e71. 